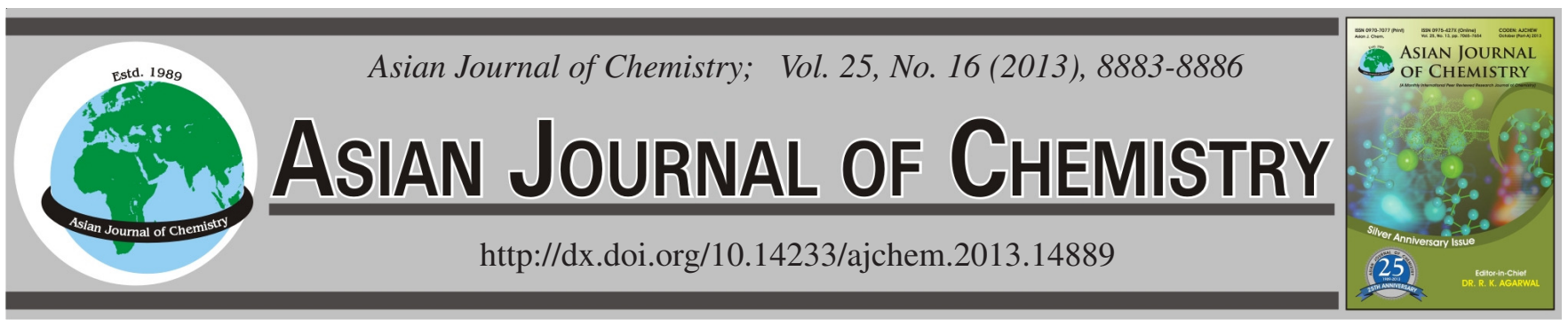

\title{
Flow-Injection Chemiluminescence Determination of Ceftezole Sodium Based on its Enhancing Effect on Luminol-Potassium Ferricyanide System
}

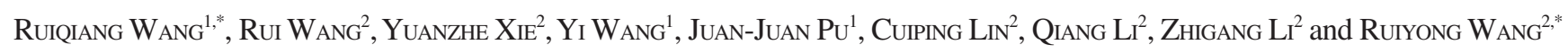

${ }^{1}$ The First Afficiated Hospiatal of Zhengzhou University, Zhengzhou University, Zhengzhou, P.R. China

${ }^{2}$ Department of Chemistry, Zhengzhou University, Zhengzhou, 450001, P.R. China

*Corresponding author: E-mail: wangruiqiang@zzu.edu.cn; wangry@zzu.edu.cn

(Received: 3 December 2012;

Accepted: 5 September 2013)

AJC-14072

\begin{abstract}
A new chemiluminescence method coupled with the flow injection technique for the determination of ceftezole sodium is developed. It is based on the enhancement of ceftezole sodium on the chemiluminescence intensity of luminol-potassium ferricyanide system in sodium hydroxide medium. This method has the advantages of high sensitivity, wide linear range, low detection limit, good reproducibility and simple instrument. Under the optimum conditions, the relative chemiluminescence intensity is proportional with the concentration of ceftezole sodium in the range of $1.0 \times 10^{-7}$ to $1.0 \times 10^{-4} \mathrm{~g} \mathrm{~mL}^{-1}$. The limit of detection is $3.0 \times 10^{-8} \mathrm{~g} \mathrm{~mL}^{-1}$ and the relative standard deviation for 11 parallel measurements of $7.0 \times 10^{-6} \mathrm{~g} \mathrm{~mL}^{-1}$ ceftezole sodium is $1.6 \%$. The proposed method has been applied to the determination of ceftezole sodium in synthetic and real samples with satisfactory results.
\end{abstract}

Key Words: Chemiluminescence, Ceftezole sodium, Luminol, Potassium ferricyanide.

\section{INTRODUCTION}

Ceftezole sodium (Fig. 1) is the first generation of semisynthetic cephalosporin derivatives anti-infective drugs. It is used to treat the respiratory infections, urinary tract infections, peritonitis, etc. ${ }^{1-4}$ For its measurement, several methods have been reported, such as UV spectrophotometry ${ }^{5,6}$ high performance liquid chromatography ${ }^{7}$. Some of these methods are time consuming and low sensitivity and volatile organic solvents are used. It is necessary to establish a simple, rapid and sensitive analytical method.<smiles>O=C(Cn1cnnn1)NC(=O)N1CSCC(CSc2nncs2)=C1C(=O)O[Na]</smiles>

Fig. 1. Chemical structure of ceftezole sodium

Chemiluminescence methods provide many advantages for pharmaceutical determinations such as high sensitivity, small amount of chemical consumption, simple sample preparation and instrumentation ${ }^{8-14}$. When coupled with flow injection analysis, the flow injection analysis-chemiluminescence methods provide low cost, rapid, simple and reproducible means and therefore, have been successfully applied to drugs detection $^{15-24}$. The aim of the present study is to use a flowinjection analysis system with chemiluminescent detection for determination of ceftezole sodium.

The chemilumionescent behaviour of ceftezole sodium in potassium luminol-ferricyanide media has been investigated. It is discovered that the chemiluminescence intensity increases when the ceftezole sodium solution is injected into the mixture of potassium ferricyanide and alkaline luminol. A simple and rapid flow injection chemiluminescence assay for ceftezole sodium based on the above mentioned discovery was developed and it was applied to the determination of ceftezole sodium in the synthetic samples and human urine samples with satisfactory results. To the best of our knowledge, this is the first report on the chemiluminescent determination of ceftezole sodium.

\section{EXPERIMENTAL}

IFFM-D flow-injection chemiluminescence analyze (Xi' an Remex Analyse Instrument Co. Ltd., Xi' an, China); IFFSA multifunctional chemiluminescent detector ( Xi'an Remex Analyse Instrument Co. Ltd., Xi' an, China); SYZ-A highpure quartz sub-boiling stills (Jiang Su, New Diligence China Quartz Glass Instrument Factory, Yi xing).

All reagents are of analytical-reagent grade unless specified otherwise; doubly distilled water is used for the preparation 
TABLE-1

EFFECT OF THREE DRUG PRETREATMENT PROCEDURES ON THE CHEMILUMINESCENCE INTENSITY

\begin{tabular}{lccc}
\hline Methods & Program A & Program B & ${\text { Program } \mathrm{C}^{\mathrm{c}}}^{\mathrm{b}}$ \\
\hline Blank CL intensity & $1657,1706,1763$ & $1774,1763,1691$ & $1866,1864,1863$ \\
Samples CL intensity & $1839,1833,1836$ & $2337,2356,2337$ & $3164,3221,3251$ \\
Relative CL intensity & 127.3 (mean) & 600.7 (mean) & 1347.7 (mean) \\
\hline${ }^{\mathrm{a}} 1.00 \mathrm{~mL}$ of $2.0 \times 10^{-5} \mathrm{~g} \mathrm{~mL}^{-1}$ ceftezole sodium solution with $0.10 \mathrm{~mL}$ of $0.10 \mathrm{~mol} \mathrm{~L}^{-1}$ sodium hydroxide solution is diluted to $10.0 \mathrm{~mL}$ with water. \\
${ }^{\mathrm{b}} 1.00 \mathrm{~mL}$ of $2.0 \times 10^{-5} \mathrm{~g} \mathrm{~mL}^{-1}$ ceftezole sodium solution with $0.10 \mathrm{~mL}$ of $0.10 \mathrm{~mol} \mathrm{~L}^{-1}$ sodium hydroxide solution is diluted to $10.0 \mathrm{~mL}$ with water \\
and hydrolysis at $100^{\circ} \mathrm{C} \mathrm{for} 10$ min. $^{\mathrm{c}} 1.00 \mathrm{~mL}$ of $2.0 \times 10^{-5} \mathrm{~g} \mathrm{~mL}^{-1}$ ceftezole sodium solution was diluted to $10.0 \mathrm{~mL}$ with water.
\end{tabular}

of solutions. Stock solutions of ceftezole sodium $\left(2.0 \times 10^{-4} \mathrm{~g}\right.$ $\mathrm{mL}^{-1}$ ) are prepared and stored in the refrigerator at $4{ }^{\circ} \mathrm{C}$, which is obtained from Henan Drug Examination Institute, China. Working standard solutions are prepared from the stock solution by appropriate dilution with water before use. Luminol stock solution $\left(2.0 \times 10^{-3} \mathrm{~mol} \mathrm{~L}^{-1}\right)$ is prepared by dissolving $0.0354 \mathrm{~g}$ of luminol which from Sigma company in $0.10 \mathrm{~mol}$ $\mathrm{L}^{-1}$ sodium hydroxide solution and diluting to $100.00 \mathrm{~mL}$ with same sodium hydroxide solution in an amber-coloured measuring flask. Stock sodium hydroxide solution $(0.10 \mathrm{~mol}$ $\left.\mathrm{L}^{-1}\right)$ is prepared daily in doubly distilled water. Potassium ferricyanide stock solution $\left(1.0 \times 10^{-3} \mathrm{~mol} \mathrm{~L}^{-1}\right)$ is prepared daily, by dissolving $0.0823 \mathrm{~g}$ of potassium ferricyanide (Austria Sheng Tian-jin Chemical Reagent Co. Ltd., Tian-jin, China) in water and diluting to $250 \mathrm{~mL}$ in an amber-coloured measuring flask.

The schematic diagram of the flow system employed in this work is shown in Fig. 2, which consists of two peristaltic pumps $\mathrm{P}_{1}$ and $\mathrm{P}_{2}$. Both the peristaltic pumps are used to deliver streams in this system. PTFE tubing $(0.8 \mathrm{~mm}$ i.d. $)$ is used to connect material in the flow system. The $7.0 \times 10^{-6} \mathrm{~g}$ $\mathrm{mL}^{-1}$ of ceftezole sodium solution merges with the mixture of alkaline luminol $\left(1.0 \times 10^{-5} \mathrm{~mol} \mathrm{~L}^{-1}\right.$, in $\left.0.10 \mathrm{~mol} \mathrm{~L}^{-1} \mathrm{NaOH}\right)$ and potassium ferricyanide $\left(1.5 \times 10^{-4} \mathrm{~mol} \mathrm{~L}^{-1}\right)$ and then reaches the flow cell, increasing chemiluminescence intensity. The change of chemiluminescence signal in the flow cell is detected with IFFS-A multifunctional chemiluminescent detector. Data acquisition and treatment are performed with Sync Master T88DF software running under Windows 98. The concentration of sample was quantified by the relative increased chemiluminescence intensity.

$\mathrm{a}$

b

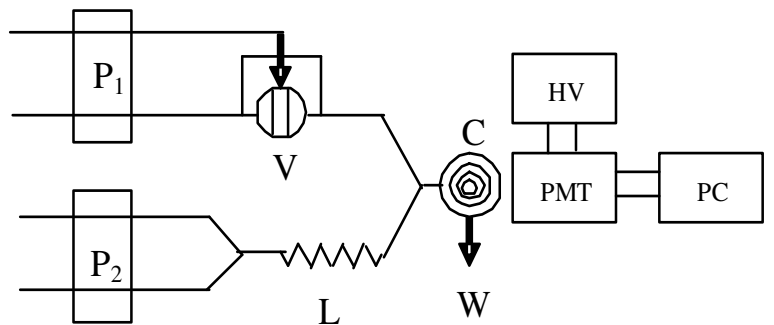

Fig. 2. Schematic diagram of the FIA-CL manifold employed for the determination of ceftezole sodium; a: sample solution or water; b: luminal solution; c: sodium hydroxide solution; d: potassium ferricyanide solution; $\mathrm{P}_{1}, \mathrm{P}_{2}$ : peristaltic pump; $\mathrm{V}$ : injection valve; $\mathrm{L}$ : mixing tube; $\mathrm{C}$ : chemiluminescence flow cell; $\mathrm{W}$ : waste solution; PMT: photomultiplier tube; HV: negative high-voltage supply; PC: computer

In order to obtain satisfied stability, the instruments are run for at least $15 \mathrm{~min}$ before the first measurement. The pumps are started to wash the whole system until a stable baseline is recorded. The flow rate is fed at $2.33 \mathrm{~mL} \mathrm{~min}^{-1}$ for luminol line. Collection of samples for $10 \mathrm{~s}$ and Rotating speed of pump is $35 \mathrm{rpm}$.

\section{RESULTS AND DISCUSSION}

Effect of mixing order on the chemiluminescence intensity: The mixing order of reactants has a great effect on the chemiluminescence intensity. Three mixing ways are tested: (sodium hydroxide + ceftezole sodium) + (luminal + potassium ferricyanide), (luminal + ceftezole sodium) + (potassium ferricyanide + sodium hydroxide) and (potassium ferricyanide + ceftezole sodium) + (luminal + sodium hydroxide) . Results show that the second way is the best one and high intensity and steady signals can be obtained.

Effect of drug pretreatment procedure on the chemiluminescence intensity: The effect of three drug pretreatment programs on the chemiluminescence intensity is tested as shown in Table-1. It is found that the program $\mathrm{C}$ is simple and satisfied. So the program $\mathrm{C}$ is chosen.

Selection of the medium: Redox reaction is the basis of chemiluminescence reaction and the chemiluminescence intensity is different for different medium. The influence of sodium carbonate, sodium bicarbonate, sodium oxalate and sodium hydroxide on the chemiluminescence intensity is investigated at concentration from 0.02 to $0.1 \mathrm{~mol} \mathrm{~L}^{-1}$ (Fig. 3). Results show them almost increasing the chemiluminescence intensity but we can receive the largest chemiluminescence signal when sodium hydroxide is used, therefore $\mathrm{NaOH}$ is chosen as the medium in this experiment. The effect of $\mathrm{NaOH}$ concentration on the chemiluminescence intensity is examined over the range of 0.02 to $0.25 \mathrm{~mol} \mathrm{~L}^{-1}$ (Fig. 4). Results show

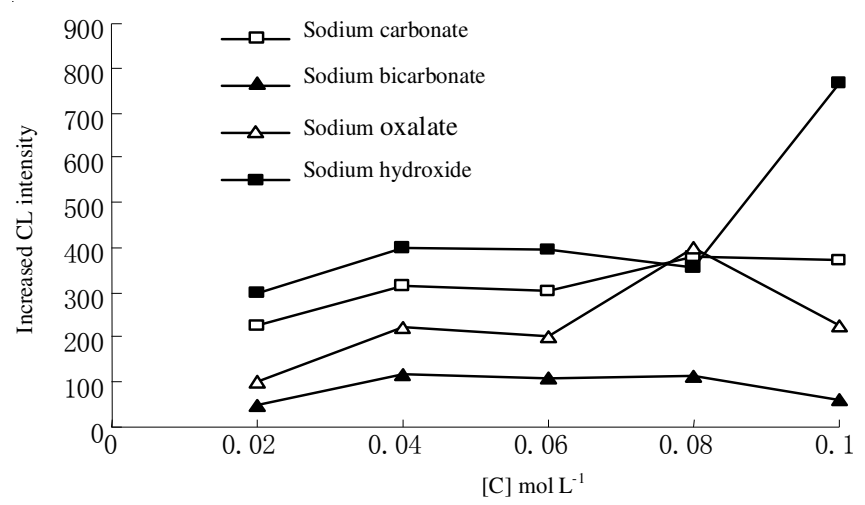

Fig. 3. Effect of the medium concentration on the chemiluminescence intensity; Potassium ferricyanide: $1.5 \times 10^{-4} \mathrm{~mol} \mathrm{~L}^{-1}$; Luminol: 1.0 $\times 10^{-5} \mathrm{~mol} \mathrm{~L}^{-1}$; Ceftezole sodium: $7.0 \times 10^{-6} \mathrm{~g} \mathrm{~mL}^{-1}$ 
TABLE-2

LINEAR RANGES AND REGRESSION EQUATIONS OF CALIBRATION CURVES

\begin{tabular}{cccc}
\hline Linear range $\left(\mathrm{g} \mathrm{mL}^{-1}\right)$ & Regression equation & Correlation coefficient & Negative high-voltage \\
\hline $1.0 \times 10^{-7}-9.0 \times 10^{-7}$ & $\Delta \mathrm{I}=2940 \times 10^{5} \mathrm{C}+466.2$ & 0.9994 & $600 \mathrm{~V}$ \\
$9.0 \times 10^{-7}-9.0 \times 10^{-6}$ & $\Delta \mathrm{I}=1266.5 \times 10^{5} \mathrm{C}+629.25$ & 0.9993 & $600 \mathrm{~V}$ \\
$9.0 \times 10^{-6}-1.0 \times 10^{-4}$ & $\Delta \mathrm{I}=667.89 \times 10^{5} \mathrm{C}+1205.7$ & 0.9985 & $600 \mathrm{~V}$ \\
\hline
\end{tabular}

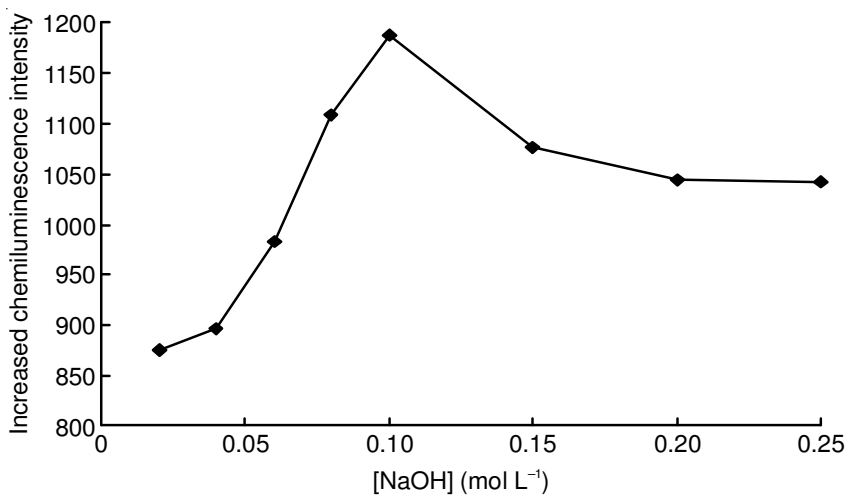

Fig. 4. Effect of $\mathrm{NaOH}$ concentration on the chemiluminescence intensity; Potassium ferricyanide: $1.5 \times 10^{-4} \mathrm{~mol} \mathrm{~L}^{-1}$; Luminol: $1.0 \times 10^{-5} \mathrm{~mol}$ $\mathrm{L}^{-1}$; Ceftezole sodium: $7.0 \times 10^{-6} \mathrm{~g} \mathrm{~mL}^{-1}$

that the strongest chemiluminescence intensity is found at a concentration of $0.10 \mathrm{~mol} \mathrm{~L}^{-1}$. Thus, $0.10 \mathrm{~mol} \mathrm{~L}^{-1}$ is selected as the optimum concentration of $\mathrm{NaOH}$ for further research.

Effect of luminol concentration on the chemiluminescence intensity: As a chemiluminescence reaction light-emitting agent, the density of luminol not only affects the chemiluminescence intensity, but also affects the sensitivity and linear range. The effect of luminol concentration on the chemiluminescence intensity is considered on the range of 2.0 $\times 10^{-6}$ to $2.0 \times 10^{-5} \mathrm{~mol} \mathrm{~L}^{-1}$ as indicated in Fig. 5. It is found that the increased chemiluminescence intensity reached maximum value when luminol concentration is $1.0 \times 10^{-5} \mathrm{~mol}$ $\mathrm{L}^{-1}$. Subsequently, the luminous intensity begins to decline and its reason may be the collision probability of excited ions after chemical reaction coming to addition with the increase of luminol concentration, then it produces quenching ${ }^{25}$. Consequently, the concentration of luminol is chosen as $1.0 \times 10^{-5}$ $\mathrm{mol} \mathrm{L} \mathrm{L}^{-1}$ for the following experiment.

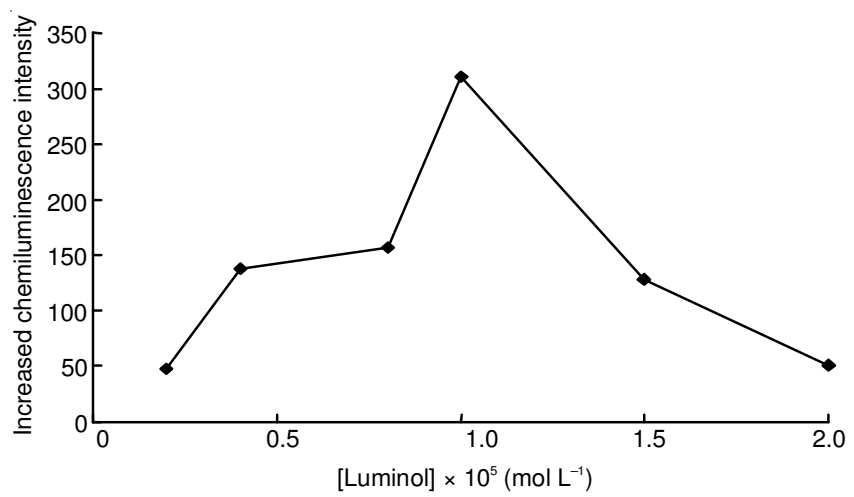

Fig. 5. Effect of luminol concentration on the chemiluminescence intensity; Potassium ferricyanide: $1.5 \times 10^{-4} \mathrm{~mol} \mathrm{~L}^{-1} ; \mathrm{NaOH}: 0.10 \mathrm{~mol} \mathrm{~L}^{-1}$; Ceftezole sodium: $7.0 \times 10^{-6} \mathrm{~g} \mathrm{~mL}^{-1}$

Selection of oxidant and the effect of its concentration on the chemiluminescence intensity: Several oxidants, including potassium ferricyanide, potassium permanganate, potassium periodate and hydrogen peroxide, were investigated. In the presence of luminol, the most significantly increased chemiluminescence signal is recorded when potassium ferricyanide is used. Therefore, a procedure based on the enhancement effect of ceftezole sodium on luminol-potassium ferricyanide reaction is proposed. Potassium ferricyanide was chosen as optimum and the effect of its concentration on the increased chemiluminescence intensity is further studied from $2.0 \times 10^{-5}$ to $2.5 \times 10^{-4} \mathrm{~mol} \mathrm{~L}^{-1}$ (Fig. 6). The results show that at the concentration higher or lower than $1.5 \times 10^{-4} \mathrm{~mol} \mathrm{~L}^{-1}$, there is a decrease in the increased chemiluminescence intensity. Thus, $1.5 \times 10^{-4} \mathrm{~mol} \mathrm{~L}^{-1}$ is selected as optimum concentration of potassium ferricyanide throughout the research.

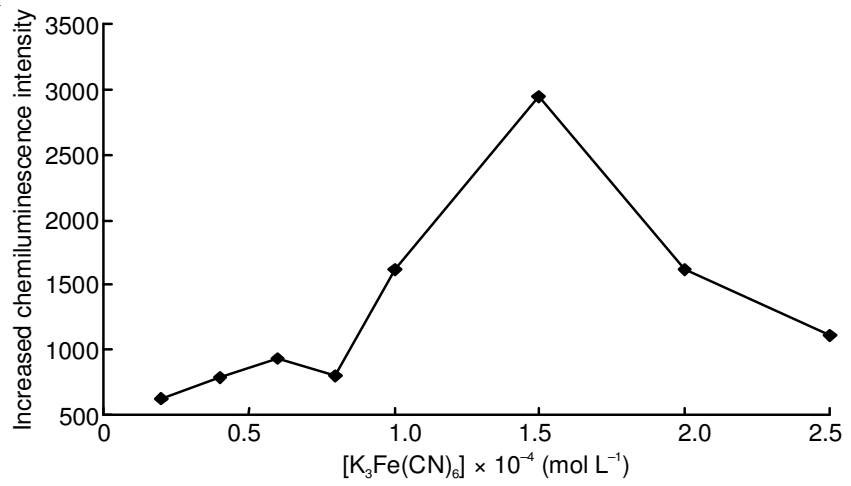

Fig. 6. Effect of $\mathrm{K}_{3} \mathrm{Fe}(\mathrm{CN})_{6}$ concentration on the chemiluminescence intensity. Luminol: $1.0 \times 10^{-5} \mathrm{~mol} \mathrm{~L}^{-1}$; NaOH: $0.10 \mathrm{~mol} \mathrm{~L}^{-1}$; Ceftezole sodium: $3.0 \times 10^{-6} \mathrm{~g} \mathrm{~mL}^{-1}$

Effects of other chemicals: The influence of surfactants and potential enhancers on the chemiluminescence intensity is studied. Surfactants (sodium dodecylbenzenesulfonate, cetyltrimethylammonium bromide and Tween 80 ) have no significant effect at a concentration of $1.0 \times 10^{-4} \mathrm{~g} \mathrm{~mL}^{-1}$. The following potential enhancers, rhodamin $\mathrm{B}\left(5.0 \times 10^{-7}\right.$ to $1.0 \times$ $\left.10^{-6} \mathrm{~mol} \mathrm{~L}^{-1}\right)$, rhodamin $6 \mathrm{G}\left(5.0 \times 10^{-7}\right.$ to $\left.1.0 \times 10^{-6} \mathrm{~mol} \mathrm{~L}^{-1}\right)$ and fluorenone $\left(5.0 \times 10^{-8}\right.$ to $\left.5.0 \times 10^{-7} \mathrm{~mol} \mathrm{~L}^{-1}\right)$ are investigated. All of them slightly enhance the chemiluminescence intensity. Therefore, surfactants and potential enhancers are not used in this study.

Calibration curves and detection limits: Under the optimum conditions, the relative chemiluminescence intensity is proportional with the concentration of ceftezole sodium in the range of $1.0 \times 10^{-7}$ to $1.0 \times 10^{-4} \mathrm{~g} \mathrm{~mL}^{-1}$ (Table-2). The limit of detection is $3.0 \times 10^{-8} \mathrm{~g} \mathrm{~mL}^{-1}$ and the relative standard deviation for 11 parallel measurements of $7.0 \times 10^{-6} \mathrm{~g} \mathrm{~mL}^{-1}$ ceftezole sodium is $1.6 \%$.

Interference studies: In order to assess the selectivity of the proposed method, the influence of the commonly used injection excipients is studied. A 1000 -fold mass excess of excipients over $7.0 \times 10^{-6} \mathrm{~mol} \mathrm{~L}^{-1}$ ceftezole sodium is tested 
TABLE-3

DETERMINATION RESULTS OF CEFTEZOLE SODIUM IN THE SYNTHETIC SAMPLES

\begin{tabular}{clcccc}
\hline Sample & Co-existing substances & $\begin{array}{c}\text { Added } \\
\left(\mathrm{g} \mathrm{mL}^{-1}\right)\end{array}$ & $\begin{array}{c}\text { Found } \\
\left(\mathrm{g} \mathrm{mL}^{-1}\right)\end{array}$ & $\begin{array}{c}\text { Recovery } \\
(\%)\end{array}$ & $\begin{array}{c}\text { R.S.D (\%) } \\
n=5\end{array}$ \\
\hline 1 & $\mathrm{KI}(10), \mathrm{KCl}(10), \mathrm{KBr}(10)$ & $2.0 \times 10^{-5}$ & $1.915 \times 10^{-5}$ & 95.75 & 0.22 \\
2 & $\mathrm{KI}(50), \mathrm{KCl}(50), \mathrm{KBr}(50)$ & $4.0 \times 10^{-5}$ & $4.196 \times 10^{-5}$ & 104.89 & 0.42 \\
3 & $\mathrm{KI}(100), \mathrm{KCl}(100), \mathrm{KBr}(100)$ & $6.0 \times 10^{-5}$ & $5.830 \times 10^{-5}$ & 97.17 & 0.08 \\
4 & $\mathrm{KI}(100), \mathrm{KCl}(100), \mathrm{KBr}(100), \mathrm{C}_{6} \mathrm{H}_{12} \mathrm{O}_{6}(2)$ & $6.0 \times 10^{-5}$ & $6.066 \times 10^{-5}$ & 101.11 & 0.67 \\
5 & $\mathrm{KI}(100), \mathrm{KCl}(100), \mathrm{KBr}(100), \mathrm{C}_{6} \mathrm{H}_{8} \mathrm{O}_{7} \cdot \mathrm{H}_{2} \mathrm{O}(5), \mathrm{C}_{6} \mathrm{H}_{5} \mathrm{Na}_{3} \mathrm{O}_{7} \cdot 2 \mathrm{H}_{2} \mathrm{O}(5)$ & $6.0 \times 10^{-5}$ & $5.808 \times 10^{-5}$ & 96.80 & 0.08 \\
\hline
\end{tabular}

TABLE-4

DETERMINATION RESULTS OF CEFTEZOLE SODIUM IN INJECTIONS

\begin{tabular}{|c|c|c|c|c|c|c|}
\hline Sample & Label (g) & Found $(\mathrm{g})$ & Added $\left(\mathrm{g} \mathrm{mL}^{-1}\right)$ & Found $\left(\mathrm{g} \mathrm{mL}^{-1}\right)$ & Recovery (\%) & R.S.D $(\%), n=5$ \\
\hline Injection 1 & 1.0 & 0.924 & $4.0 \times 10^{-5}$ & $3.656 \times 10^{-5}$ & 91.40 & 0.03 \\
\hline Injection 2 & 1.0 & 0.932 & $4.0 \times 10^{-5}$ & $3.723 \times 10^{-5}$ & 93.08 & 0.14 \\
\hline Injection 3 & 1.0 & 0.936 & $4.0 \times 10^{-5}$ & $3.704 \times 10^{-5}$ & 92.59 & 0.10 \\
\hline
\end{tabular}

first. If interference occurred, the ratio would reduce progressively until the interference ceased. The criterion for interference is fixed at a $\pm 5.0 \%$ variation of the average chemiluminescence intensity calculated for the established level of ceftezole sodium. No interference has been found when including up to a 100-fold $\mathrm{KCl}, \mathrm{KBr}, \mathrm{KI}$; 5-fold $\mathrm{C}_{6} \mathrm{H}_{5} \mathrm{O}_{7} \mathrm{Na}_{3}$, $\mathrm{HOC}\left(\mathrm{CH}_{2} \mathrm{COOH}\right)_{2} \mathrm{COOH}$; 2-fold $\mathrm{CaCl}_{2}$ and equal amount of $\mathrm{C}_{4} \mathrm{H}_{6} \mathrm{O}_{6} \cdot \mathrm{H}_{2} \mathrm{O}, \mathrm{C}_{6} \mathrm{H}_{12} \mathrm{O}_{6}$ and $\mathrm{ZnSO}_{4}$.

Analysis of synthetic and real samples: $0.03 \mathrm{~g}$ of ceftezole sodium is mixed with different foreign substances and stored in an amber-coloured measuring flask with the volume of $50 \mathrm{~mL}$. Working solutions are diluted with water so that the concentration of ceftezole sodium in the final solution is within the working range. The results of the determination of ceftezole sodium in synthetic samples are shown in Table-3.

As described above, the application of this method was assayed by determining the concentration of ceftezole sodium in injection samples as shown in Table-4.

The method presented here has a low detection limit and, therefore, the proposed method allows the determination of ceftezole sodium in urine samples. Add a certain amount of standard solution of ceftezole sodium to the urine sample. Filter after centrifugation for $10 \mathrm{~min}$ in order to remove impurities in urine. Transfer $1 \mathrm{~mL}$ of solution into a $50 \mathrm{~mL}$ of amber-coloured measuring flask and dilute to volume with water. Proceed as described above, a blank value is determined by treating ceftezole sodium-free urine sample in the same way. Calculations of recovery are shown in Table-5.

TABLE-5

RECOVERY OF CEFTEZOLE SODIUM IN URINE SAMPLES

\begin{tabular}{cccc}
\hline $\begin{array}{c}\text { Added } \\
\left(\mathrm{g} \mathrm{mL}^{-1}\right)\end{array}$ & $\begin{array}{c}\text { Found } \\
\left(\mathrm{g} \mathrm{mL}^{-1}\right)\end{array}$ & $\begin{array}{c}\text { Recovery } \\
(\%)\end{array}$ & $\begin{array}{c}\text { R.S.D }(\%), \\
n=5\end{array}$ \\
\hline $2.0 \times 10^{-5}$ & $1.997 \times 10^{-5}$ & 99.85 & 0.32 \\
$4.0 \times 10^{-5}$ & $3.972 \times 10^{-5}$ & 99.30 & 0.46 \\
$6.0 \times 10^{-5}$ & $5.923 \times 10^{-5}$ & 98.72 & 0.36 \\
\hline
\end{tabular}

\section{Conclusion}

In this paper, a flow-injection chemiluminescence method is proposed to determine ceftezole sodium in synthetic and urine samples with satisfactory results. This method does not require special reagents and offers advantages of simplicity, rapidity, high sensitivity and wide linear range.

\section{ACKNOWLEDGEMENTS}

The authors are indebted to the National Natural Science Foundation of China (No. 20905065) and the Natural Science Foundation of Henan Province (2008A180032, 2010A150024) for funding.

\section{REFERENCES}

1. A. De Sarro, G.B. De Sarro, C. Ascioti and G. Nisticó, Neuropharmacology, 28, 359 (1989).

2. D.S. Lee, J.M. Lee, S.U. Kim, K.T. Chang and S.H. Lee, Int. J. Mol. Med., 20, 379 (2007).

3. C. Hu, S. Cheng and L. Lu, Yaoxue Xuebao, 37, 275 (2002).

4. C. Hubschwerlen, in eds.: J.B. Taylor and David J. Triggle, Comprehensive Medicinal Chemistry II, Amsterdam, Elsevier, Chap. 7, vol. 17, p. 479 (2007).

5. H. Ji, Y. Wang and L. Wang, Acta Acad. Med. Xuzhou, 24, 535 (2004).

6. B. Morelli, Anal. Chim. Acta, 209, 175 (1988).

7. X. Chen, Strait Pharm.. J., 15, 37 (2003).

8. A. Waseem, M. Yaqoob and A. Nabi, Anal. Sci., 25, 395 (2009).

9. S. Kanwal, X.H. Fu and X.G. Su, Spectrochim. Acta A, 74, 1046 (2009).

10. W. Xu, Y.C. Wei, D. Xing and Q. Chen, Anal. Sci., 24, 115 (2008).

11. W. Ruengsitagoon, S. Liawruangrath and A. Townshend, Talanta, 69, 976 (2006)

12. A. Waseem, L. Rishi, M. Yaqoob and A. Nabi, Anal. Sci., 25, 407 (2009).

13. Y. Huang and W. Liu, J. Pharm. Biomed. Anal., 38, 537 (2005).

14. H. Liu, L. Zhang and J. Zhou, Y. Hao, P. He and Y. Fang, Anal. Chim. Acta, 541, 12 (2005).

15. N.A. Al-Arfai, E.A. Al-Abdulkareem and F.A. Aly, Anal. Sci., 25, 401 (2009).

16. J. Du, L. Shen and J. Lu, Anal. Chim. Acta, 489, 183 (2003).

17. L. Hao, J.X. Du and J.R. Lu, Anal. Sci., 23, 597 (2007).

18. Z. Song, T. Zhao, L. Wang and Z. Xiao, Bioorg. Med. Chem., 9, 1701 (2001).

19. H. Bai, F. Nie and J.R. Lu, Anal. Sci., 23, 1301 (2007).

20. B. Li and Z. Zhang, Sens. Actuators B, 69, 70 (2000).

21. H.W. Sun, L.Q. Li and X. Chen, Anal. Sci., 22, 1145 (2006).

22. D.Y. Zhang, Y.J. Ma, M. Zhou, L. Li and H. Chen, Anal. Sci., 22, 183 (2006).

23. J. Ouyang, W. Baeyens, J. Delanghe, G. Van der weken and A.C Calokerinos, Talanta, 46, 961 (1998).

24. B.J. Hindson and N.W. Barnett, Anal. Chim. Acta, 445, 1 (2001).

25. J.K. Wong and M.L. Salin, Photochem. Photobiol., 33, 737 (1981). 